\title{
Evaluation of Anti-DFS70 antibodies and DFS pattern in ANA positive individuals and ANA Associated Rheumatic Diseases
}

\author{
ANA Pozitif Bireylerde ve ANA İlişkili Romatizmal Hastalıklarda Anti-DFS70 Antikorlarının ve DFS \\ Paterninin Değerlendirilmesi
}

Sevcan Uğur ${ }^{*}$, Tuğba Kula Atik ${ }^{2}$

1.Department of Physical Medicine and Rehabilitation, Division of Rheumatology Alanya Alaaddin Keykubat University School of Medicine, Antalya, Turkey

2.Department of Microbiology, Ballkesir University School of Medicine Balıkesir Turkey

\section{ABSTRACT}

Aim: In this study we aimed to find the frequency of anti-DFS70 antibodies and DFS pattern in ANA positive individuals and ANA associated rheumatic diseases (AARDs). Methods: In this study, 337 subjects who were evaluated in a rheumatology clinic with prediagnosis of rheumatic diseases with positive ANA test and had concurrent anti-extractable nuclear antigen (anti-ENA) antibodies results were retrospectively analyzed. Clinical diagnosis of patients and demographic characteristics were obtained from the patients' medical records.

Results: A total of 337 subjects ( 305 women, 32 men) were included in this study. The mean age was $49.8 \pm 14.2$ years. Of the 337 participants, $111(32.9 \%)$ had an IIF-DFS pattern and $226(67.1 \%)$ had a non-DFS pattern. Anti-DFS70 antibodies were positive in $20.1 \%$ of individuals. Sixty eight individuals had AARDs. An IIF-DFS pattern was observed in $22.1 \%$ and a non-DFS pattern was observed in $77.9 \%$ of individuals with AARDs $(p<0.05)$. Anti-DFS70 antibodies were positive in $13.2 \%$ of patients with AARDs. The frequency of AARDs was significantly lower in individuals with anti-DFS70 antibodies compared to individuals with other anti-ENAs antibodies $(p<0.05)$.

Conclusion: Anti-DFS70 antibodies may be present in patients with AARDs but AARDs are less prevalent in patients who had anti-DFS70 antibodies, compared with patients who had other anti-ENAs.

Key words: Antinuclear antibodies (ANA), Anti DFS70 antibody, DFS pattern

\section{Öz}

Amaç: Bu çalışmada, ANA pozitif bireylerde ve ANA ilişkili romatizmal hastalıklarda anti-DFS70 antikor ve DFS patern sıklığını bulmayı amaçladık.

Yöntem: Bu çalışmada romatoloji kliniğinde romatizmal hastalık ön tanısı ile değerlendirilen, ANA tetkiki pozitif olan ve es zamanlı anti-ekstrakte edilebilir nükleer antijen (anti-ENA) antikor sonucu olan 337 kişi retrospektif olarak incelendi. Hastaların klinik tanıları ve demografik özellikleri hasta tıbbi kayıtlarından elde edildi. Bulgular: Bu çalışmaya toplam 337 (305 kadın, 32 erkek) kişi dahil edildi. Yaş ortalaması $49.8 \pm 14.2$ yıl idi. 337 katılımcının 111'i (\%32.9) IIF-DFS paterne, 226's (\%67.1) DFS dışı paterne sahipti. Bireylerin \%20.1'inde anti-DFS70 antikoru pozitifti. 68 kişide ANA ilişkili romatizmal hastalık vardı. ANA ilişkili romatizmal hastalı̆a sahip kişilerin \%22.1'inde IIF-DFS patern, \%77.9'unda DFS dışı patern gözlendi ( $p<0.05)$ ANA ilişkili hastalığa sahip kişilerin \%13.2'sinde anti-DFS70 antikoru pozitifti. Anti-DFS70 antikoruna sahip kişilerde diğer anti-ENA antikorlarına sahip kişilerle karşılaştııılığında ANA ilişkili romatizmal hastalık sıkığı anlamlı ölçüde düşüktü $(p<0,05)$.

Sonuç: Anti-DFS70 antikorlar ANA ilişkili romatizmal hastalıklarda bulunabilir ancak ANA ilişkili romatizmal hastalıklar anti-DFS70 antikorlarına sahip kişilerde diğer antiENA antikorlarına sahip kişilere kıyasla daha az yaygındır.

Anahtar kelimeler: Anti nükleer antikorlar (ANA), Anti DFS70 antikor, DFS patern

Received: 15.06.2021 Accepted: 25.07.2021 Published (Online):31.12.2021

*Corresponding Author: Sevcan Uğur. Alanya Alaaddin Keykubat University School of Medicine, Department of Physical Medicine and Rehabilitation, Division of Rheumatology, Antalya, Turkey,+905052642589,dr_sevcanugur@hotmail.com ORCID: 0000-0001-5617-629X

To cited: Uğur S, Atik TK. Evaluation of Anti-DFS70 antibodies and DFS pattern in ANA positive individuals and ANA Associated Rheumatic Diseases. Acta Med. Alanya 2021;5(3):234-238 doi:10.30565/medalanya.952813 


\section{INTRODUCTION}

A ntinuclear antibodies (ANA) are assay markers for diagnosis of ANA associated rheumatic diseases (AARDs) such as systemic lupus erythematosus (SLE), Sjögren's syndrome (SjS), mixed connective tissue disease (MCTD) and systemic sclerosis (SSc) [1]. The indirect immunofluorescence (IIF) assay is mostly used for the detection of ANA and proposed as a screening test by the American College Rheumatology (ACR) [2]. Anti-Dense Fine Speckled 70 (DFS70) antibodies were identified as related to specific IIFANA pattern. The DFS pattern is characterized by irregularly distributed, fine-granular fluorescence of the nuclei and has shown reactivity of the autoantibody with a $70 \mathrm{kD}$ protein [3,4]. AntiDFS70 antibodies are related with different status [5]. DFS70 pattern and anti-DFS70 antibodies have been stated more commonly in healthy individuals compared to systemic rheumatic diseases [6,7]. Anti-DFS70 antibodies have been defined as an eventual marker for the ruling out systemic autoimmune diseases (SARDs) [8].

In this retrospective study we aimed to determine the frequency of anti-DFS70 antibodies and IIFDFS pattern in IIF-ANA positive individuals and patients with AARDs.

\section{MATERIALS AND METHODS}

In this retrospective study, 337 subjects with positive ANA test and who simultaneously had antiENAs antibodies results and who were evaluated with a prediagnosis of rheumatic diseases in the rheumatology outpatient clinic between 2018 and 2019, were consecutively included. ANA was detected using the indirect immunofluorescence (IIF) method (IIF Mosaic: Hep-20-10/Liver (Monkey) kit, Euroimmun, Germany). ANA at titer $\geq$ $1 / 160$ was considered as positive. An ANA Profile 3 plus DFS70-IgG kit (Euroimmun, Germany) was used for the anti-ENAs test. Autoantibodies against nuclear ribonucleoprotein (nRNP), Smith (Sm), SS-A/Ro-52, SS-B, Scl-70, PM-Scl, Jo-1, centromere protein $B$ (CENP-B), double-stranded DNA (dsDNA), nucleosome, histone, ribosomal $P$-protein and anti-mitochondrial antibodies (AMA) autoantigens were evaluated in the ANA profile. Demographic characteristics of the individuals, ANA pattern, anti-ENAs test results and diagnosis of AARDs were recorded from the electronic file. AARDs consisted of SLE, SS, undifferentiated connective tissue disease (UCTD), SSc, myositis, drug induced SLE and SLE/SSc overlap.

Statistics: Categorical data is shown as counts and percentages. Continuous data is shown as means and standard deviations (SD). The Pearson chi-square test was used to compare the qualitative results. The IBM-SPSS16 was used in all statistical analyses and the $p$ value $<0.05$ was considered statistically significant. This study was performed according to the Declaration of Helsinki. Permission for the study was obtained from the Balıkesir University Faculty of Medicine Ethics Committee, decision number 190 in 04/12/2019.

\section{RESULTS}

In this study a total of 337 individuals ( 305 female, 32 male) with positive ANA and simultaneously anti-ENAs test results were included. The mean age was $49.87 \pm 14.29$ years (female: $50.10 \pm 13.92$ years, male: $47.75 \pm 17.49$ years $p>0.05)$. An IIF-DFS pattern was observed in $32.9 \%$ of 337 individuals.

Anti-DFS70 antibodies were positive in 68 (20.2\%) of the 337 subjects (Table 1). Among these, 64 $(94.1 \%)$ had isolated anti-DFS70 antibody (antiDFS70 antibody positive, with other anti-ENAs being negative). Among anti-DFS70 antibody positive subjects, four had additional anti-ENAs specificity (1 anti-SS-A, $1 \mathrm{pm}-\mathrm{scl}, 1$ anti-histone, 1 anti-SCL-70 antibody). Anti-DFS70 antibodies were present in 54 of the $111(48.6 \%)$ subjects with IIF-DFS pattern (53 isolated anti DFS70 antibodies positive, 1 additional anti ENAs being positive). Fourteen of 226 (6.2\%) subjects with other IIF-ANA patterns had anti-DFS70 antibodies. Among DFS pattern positive subjects, 58 individuals had $>1 / 160$ titer, 37 individuals had $\geq 1 / 320$ titer, 14 individuals had $\geq 1 / 640$ titer and 2 individuals had $\geq 1 / 1280$ titer. Anti-DFS70 antibodies were positive in $85 \%$ of the subjects who had IIF-DFS titers $\geq 1 / 640$ and $43.1 \%$ of the subjects who had $>1 / 160$ IIF DFS titer. The mean age was $46.93 \pm 14.17$ in subjects who had antiDFS70 antibodies and $50.62 \pm 14.25$ in subjects who did not $(p<0.05)$.

Sixty-eight of 337 (20.1\%) individuals had AARDs 
(19 SLE, 21 SS, 21 UCTD, 3 SSc, 1 myositis, 2 drug induced SLE, 1 SLE/SSc overlap). The DFS pattern was observed in $22.1 \%$ of $(15 / 68)$ patients with AARDs. The frequency of AARDs was $13.2 \%$ $(15 / 111)$ in individuals with DFS pattern and 23.5 $\%(53 / 226)$ in individuals with non DFS pattern $(p<0.05)$. The anti-DFS70 antibodies were positive in $13.2 \%(n=9)$ of 68 patients with AARDs. The other anti-ENAs antibodies were positive in $42.6 \%$ $(n=29)$ of 68 patients with AARDs. The frequency of AARDs was significantly lower in the individuals with anti DFS70 antibodies compared to those with other anti-ENAs specificity $(p<0.05)$. Among 68 patients with AARDs, 6 patients had isolated anti-DFS70 antibody positivity and 3 patients had additional anti-ENAs specificity. Clinical diagnosis of anti-DFS70 positive subjects were 3 UCTD, 2 SLE and 4 SS. The distribution of AARDs, according to IIF-DFS and anti DFS70 antibody status, is shown in (Table 2).

Table 1. Frequency of IIF-DFS, anti-DFS70 antibody and AARD

\begin{tabular}{|c|c|c|}
\hline & \multicolumn{2}{|c|}{ noun/percent } \\
\hline & $\begin{array}{l}\text { Total } \\
(337)\end{array}$ & $\begin{array}{l}\text { AARDs } \\
(68)\end{array}$ \\
\hline $\begin{array}{l}\text { IIF-ANA } \\
\text {-ANA positive } \\
\text {-DFS pattern positive } \\
\text {-Non DFS pattern }\end{array}$ & $\begin{array}{l}337 \\
111(32.9) \\
226(67.1)\end{array}$ & $\begin{array}{l}68 \\
15(22.1) \\
53(77.9)\end{array}$ \\
\hline $\begin{array}{l}\text { IB Anti ENA } \\
\text {-Anti-DFS70 positive } \\
\text {-İsolated anti DFS70 positive } \\
\text {-Anti-DFS70 and additional ENAs positive } \\
\text {-İsolated anti ENAs positive }\end{array}$ & $\begin{array}{l}68(20.2) \\
64(18.9) \\
4(1.2) \\
39(11.6)\end{array}$ & $\begin{array}{l}9(13.2) \\
6(8.8) \\
3(4.4) \\
29(42.2)\end{array}$ \\
\hline $\begin{array}{l}\text { IIF-ANA and Anti ENA Combination } \\
\text {-DFS pattern positive and anti DFS70 } \\
\text { positive }\end{array}$ & $54(16.02)$ & $7(10.2)$ \\
\hline $\begin{array}{l}\text {-DFS pattern positive and isolated anti } \\
\text { DFS70 positive }\end{array}$ & $53(15.72)$ & $6(8.8)$ \\
\hline $\begin{array}{l}\text {-DFS pattern positive and anti DFS70 } \\
\text { additional anti ENAs positive }\end{array}$ & $1(0.29)$ & $1(1.4)$ \\
\hline $\begin{array}{l}\text {-DFS pattern positive and isolated anti } \\
\text { ENAs positive }\end{array}$ & $4(1.18)$ & $3(4.4)$ \\
\hline $\begin{array}{l}\text {-DFS pattern negative and anti DFS } 70 \\
\text { positive }\end{array}$ & $13(3.85)$ & $3(4.4)$ \\
\hline
\end{tabular}

The positive predictive value of IIF-DFS pattern to detect AARDs was $13.5 \%$ and the positive predictive value of anti-DFS70 antibodies to detect AARDs was $13.2 \%$ (Table 3 ).
Table 2. The frequency of anti-DFS70 antibody and IIF-DFS pattern in AARDs.

\begin{tabular}{|c|c|c|c|c|c|}
\hline & $\begin{array}{l}\text { IIF } \\
\text { DFS70 } \\
\text { pattern } \\
\text { N (\%) }\end{array}$ & $\begin{array}{l}\text { Non } \\
\text { IIF } \\
\text { DFS } \\
\text { pattern }\end{array}$ & $\begin{array}{l}\text { Anti } \\
\text { DFS70 } \\
\text { antibody } \\
(+)\end{array}$ & $\begin{array}{l}\text { Anti } \\
\text { DFS70 } \\
\text { antibody } \\
(-)\end{array}$ & $\begin{array}{l}\text { Total } \\
\text { (n) }\end{array}$ \\
\hline $\begin{array}{l}\text { Systemic Lupus } \\
\text { Eritematozus } \\
\text { (SLE) }\end{array}$ & $\begin{array}{c}6 \\
(5.4 \%)\end{array}$ & $\begin{array}{c}13 \\
(5.8 \%)\end{array}$ & $\begin{array}{c}2 \\
(3 \%)\end{array}$ & $\begin{array}{c}17 \\
(6.3 \%)\end{array}$ & 19 \\
\hline $\begin{array}{l}\text { Sjögren Syndrome } \\
\text { (SS) }\end{array}$ & $\begin{array}{c}6 \\
(5.4 \%)\end{array}$ & $\begin{array}{c}15 \\
(6.6 \%)\end{array}$ & $\begin{array}{c}4 \\
(6 \%)\end{array}$ & $\begin{array}{c}17 \\
(6.3 \%)\end{array}$ & 21 \\
\hline $\begin{array}{l}\text { Undifferansiye } \\
\text { konnective tissue } \\
\text { disease }\end{array}$ & $\begin{array}{c}3 \\
(2.7 \%)\end{array}$ & $\begin{array}{c}18 \\
(8 \%)\end{array}$ & $\begin{array}{c}3 \\
(4.5 \%)\end{array}$ & $\begin{array}{c}18 \\
(6.7 \%)\end{array}$ & 21 \\
\hline Systemic Sclerosis & & $\begin{array}{c}3 \\
(1.3 \%) \\
\end{array}$ & & $\begin{array}{c}3 \\
(1.1 \%) \\
\end{array}$ & 3 \\
\hline Drug induced SLE & & $\begin{array}{c}2 \\
(0.9 \%) \\
\end{array}$ & & $\begin{array}{c}2 \\
(0.7 \%) \\
\end{array}$ & 2 \\
\hline SLE/SS overlap & & $\begin{array}{c}1 \\
(0.4 \%) \\
\end{array}$ & & $\begin{array}{c}1 \\
(0.4 \%) \\
\end{array}$ & 1 \\
\hline Myositis & & $\begin{array}{c}1 \\
(0.4 \%) \\
\end{array}$ & & $\begin{array}{c}1 \\
(0.4 \%) \\
\end{array}$ & 1 \\
\hline Total & 15 & 53 & 9 & 59 & 68 \\
\hline
\end{tabular}

Table 3. The IIF-DFS pattern and anti DFS70 antibody in detection of AARDs

\begin{tabular}{|l|l|l|}
\hline $\mathrm{n}=337$ & $\begin{array}{l}\text { IIF DFS pattern } \\
\text { positive }\end{array}$ & $\begin{array}{l}\text { Anti DFS70 antibody } \\
\text { positive }\end{array}$ \\
\hline AARD negative $(\mathrm{n}=269)$ & 96 & 59 \\
\hline AARD positive $(\mathrm{n}=68)$ & 15 & 9 \\
\hline Total & 111 & 68 \\
\hline
\end{tabular}

Discussion: In this study, we aimed to investigate the frequency of IIF-DFS pattern and anti-DFS70 antibodies in ANA positive individuals and determine whether IIF-DFS pattern and antiDFS70 antibodies were important to exclude the diagnosis of AARDs. The DFS pattern has been defined as the AC-2 pattern by an international ANA consensus algorithm. Although the intensely stained metaphase chromosome plate is an important feature of the AC-2 pattern, the entire speckled nuclear patterns with positive staining of the metaphase plate are not all AC-2. Mahler et al. developed the "pseudo-DFS" pattern description and stated that this pattern was responsible for most of the AC-2 patterns that did not show antiDFS70 reactivity $[9,10]$. In our study we found IIFDFS pattern in $32.9 \%$ (111) of the 337 individuals. Carter et al. reported a DFS pattern in $32.9 \%$ of 5339 ANA positive samples. and Dellevance et al. reported $37 \%$ DFS pattern among 13641 ANA 
positive samples [5,7]. The presence of antiDFS70 antibodies was reported from $60.2 \%$ to $91 \%$ in subjects with IIF-DFS pattern [11,12]. In our study, anti-DFS70 antibodies were positive in $48.6 \%$ of subjects with IIF-DFS pattern and the percent of anti-DFS70 antibody positivity was lower at a low titer IIF-DFS pattern, compared to high titer IIF-DFS patterns. Similar to our study, Jeon et al. found that the anti-DFS70 antibody positivity was lower at low titer IIF- DFS pattern [13]. In our study, anti-DFS70 antibodies were not positive in all individuals who had an IIFDFS pattern. We think that our results may be related to a pseudo DFS pattern and IIF-DFS positivity should be confirmed with the antiDFS70 antibody test. Anti-DFS70 antibodies are rarely seen in systemic rheumatic diseases and it has been reported that they can be used to rule out SARDs [14]. Mahler et al. showed that antiDFS70 antibodies were more common in healthy individuals $(8.9 \%)$ than patients with SARDs $(2.8 \%)$ [15]. Inversely in a recent study, Infantino et al. found no differences between AARDs and non-AARDs individuals though in their study, all of anti-DFS70 antibody positive AARDs patients had concomitant anti-ENAs specificity [1]. Muro et al. detected the anti-DFS70 antibodies in $4.4 \%$ of 500 subjects with different types of rheumatic diseases. They emphasized that patients with isolated anti-DFS70 antibodies were infrequently diagnosed with autoimmune rheumatic diseases [16].

On the other hand, Peker et al. found that the frequency of anti-DFS70 antibodies was statistically significantly higher in subjects with SARDs compared to donor serums [17]. Türkoglu et al. found that anti-DFS70 antibodies were positive in $91.7 \%$ of subjects with IIF-DFS pattern and they reported that all subjects had isolated positivity [18]. In our study, isolated positivity was found in $94.1 \%$ of anti-DFS70 antibody positive individuals and $13.2 \%$ of subjects with AARDs were positive for anti-DFS70 antibodies. AntiDFS70 positivity was statistically significantly lower in individuals with AARDs.

Our report supports that anti-DFS70 antibodies may be present in patients with AARDs, but AARDs are less prevalent in patients who had anti-DFS70 antibodies. Our study differentiates itself from other studies related with anti-DFS70 antibodies because we examined the predictive value of DFS pattern and anti-DFS70 antibodies for the diagnosis of AARDs and we found that the positive predictive values of DFS pattern and anti-DFS70 antibodies were very low. This finding supports that the fact that anti-DFS70 antibody positivity is an important marker to exclude AARDs.

Limitations: This study was designed retrospectively. The study group consisted of individuals who were evaluated with a prediagnosis of rheumatic disease. Prospective monitoring of whether AARDs will develop in subjects with anti-DFS70 antibodies will contribute to the determination of the role of anti-DFS70 antibodies in rheumatic diseases.

Conclusion: Anti-DFS70 antibodies may be present in patients with AARDs, but AARDs are less prevalent in patients who had anti-DFS70 antibodies compared to patients who had other anti ENAs specificity.

Conflict of Interest: The author declares no conflict of interest related to this article.

Funding sources: The author declares that this study has received no financial support

Ethics Committee Approval: Balıkesir Universitiy, Medical Faculty Clinical Ethics Board - 2019/190

Peer-review: Externally and internally peer reviewed.

\section{REFERENCES}

Infantino M, Pregnolato F, Bentow C, Mahler M, Benucci M, Li Gobbi F, et al. Only monospecific anti-DFS70 antibodies aid in the exclusion of antinuclear antibody associated rheumatic diseases: an Italian experience. Clin Chem Lab Med. 2019;57(11):1764-9. doi: 10.1515/cclm-2019-0454.

2. Meroni PL, Schur PH. ANA screening: An old test with new recommendations. Ann Rheum Dis. 2010;69(8):1420-2. doi: 10.1136/ard.2009.127100.

3. Conrad K, Röber N, Andrade LE, Mahler M. The clinical relevance of anti-DFS70 autoantibodies. Clin Rev Allergy Immunol. 2017;52(2):202-16. doi: 10.1007/s12016-0168564-5.

4. Carbone T, Pafundi V, Tramontano G, Gilio M, Padula MC, Padula AA, et al. Prevalence and serological profile of anti-DFS70 positive subjects from a routine ANA cohort. Sci Rep. 2019;9(1):2177. doi: 10.1038/s41598-019-38686-5.

5. Carter JB, Carter S, Saschenbrecker S, Goeckeritz BE. Recognition and relevance of anti-DFS70 autoantibodies in routine antinuclear autoantibodies testing at a Community Hospital. Front Med (Lausanne). 2018;5:88. doi: 10.3389/fmed.2018.00088.

6. Mariz HA, Sato El, Barbosa SH, Rodrigues SH, Dellavance A, Andrade LE. Pattern on the antinuclear antibody-HEp-2 test is a critical parameter for discriminating antinuclear antibody-positive healthy individuals and patients with autoimmune rheumatic diseases. Arthritis Rheum. 2011;63(1):191-200. doi: 10.1002/art.30084.

7. Dellavance A, Viana VST, Leon EP, Bonfa ESDO, Andrade LEC, Leser PG. The clinical spectrum of antinuclear antibodies associated with the nuclear dense fine speckled immunofluorescence pattern. J Rheumatol. 2005;32(11):2144-9. PMID: 16265692. 
8. Mahler M, Hanly JG, Fritzler MJ. Importance of the dense fine speckled pattern on HEp2 cells and anti-DFS70 antibodies for the diagnosis of systemic autoimmune diseases. Autoimmun Rev. 2012;11(9):642-5. doi: 10.1016/j.autrev.2011.11.005.

9. Damoiseaux J, von Muhlen CA, Garcia-de la Torre I, Carballo OG, de Melo Cruvine W, Francescantonio PLC, et al. International consensus on ANA patterns (ICAP): the bumpy road towards a consensus on reporting ANA results. Auto Immun Highlights. 2016;7(1):1. doi: 10.1007/s13317-016-0075-0.

10. Mahler M, Andrade LE, Casiano CA, Malyavantham K, Fritzler MJ. Anti-DFS70 antibodies: an update on our current understanding and their clinical usefulness. Expert Rev Clin Immunol. 2019;15(3):241-50. doi: 10.1080/1744666X.2019.1562903.

11. Miyara M, Albesa R, Charuel JL, El Amri M, Fritzler MJ, GhillaniDalbin P, et al. Clinical phenotypes of patients with anti-DFS70/ LEDGF antibodies in a routine ANA referral cohort. Clin Dev Immunol. 2013:2013:703759. doi: 10.1155/2013/703759.

12. Lee H, Kim Y, Han K, Oh EJ. Application of anti-DFS70 antibody and specific autoantibody test algorithms to patients with the dense fine speckled pattern on HEp-2 cells scand. J Rheumatol. 2016;45(2):122-8. doi: 10.3109/03009742.2015.1060260.

13. La Jeon Y, Kang SY, Lee WI, Kim MH. Clinical aspects of the dense fine speckled pattern in indirect immunofluorescence-antinuclear antibody screening and its association with DFS70 autoantibodies. Ann Clin Lab Sci. 2019;49(4):496-502. PMID: 31471339.

14. Watanabe A, Kodera M, Sugiura K, Usuda T, Tan EM, Takasaki Y, et al. Anti-DFS70 antibodies in 597 healthy hospital workers. Arthritis Rheum. 2004;50(3):892-900. doi: 10.1002/art.20096

15. Mahler M, Parker T, Peebles CL, Andrade LE, Swart A, Carbone Y, et al. Anti-DFS70/ LEDGF antibodies are more prevalent in healthy individuals compared to patients with systemic autoimmune rheumatic diseases. J Rheumatol. 2012;39(11):2104-10. doi: 10.3899/jheum.120598.

16. Muro $Y$, Sugiura K, Morita $Y$, Tomita $Y$. High concomitance of disease marker autoantibodies in anti-DFS70/LEDGF autoantibody-positive patients with autoimmune rheumatic disease. Lupus. 2008;17(3):171-6. doi: 10.1177/0961203307086311.

17. Peker BO, ŞenerAG, Tarhan EF, Kaya S. Investigation of anti-DFS70 antibody in patients with systemic autoimmune rheumatic diseases. Clin Rheumatol. 2019;38(12):3627-33. doi: 10.1007/s10067-019-04730-y.

18. Türkoğlu G, Berkem R, Karakoç AE. Investigation of the diagnostic value of anti-dense fine speckled 70/lens epithelium derived growth factor p75 autoantibody for autoimmune diseases. Mikrobiyol Bul. 2018;52(4):413-24. doi: 10.5578/mb.67385.

\begin{tabular}{|l|l|}
\hline Author / ORCID & Authorship Contrubition \\
\hline $\begin{array}{l}\text { Sevcan Uğur } \\
\text { 0000-0001-5617-629X }\end{array}$ & $\begin{array}{l}\text { Consept and/or Design, Materials } \\
\text { and/or Practices, Data collection } \\
\text { and/or Processing Analysis and/or } \\
\text { Interpretation, Literatüre Review and/ } \\
\text { or Search, Manuscript Writing and/ } \\
\text { or Final approva, Süpervision and/or } \\
\text { Critical Review }\end{array}$ \\
\hline $\begin{array}{l}\text { Tuğba Kula Atik } \\
\text { 0000-0002-2433-1977 }\end{array}$ & $\begin{array}{l}\text { Materials and/or Practices, Data } \\
\text { collection and/or Processing, Analysis } \\
\text { and/or Interpretation ,Literatüre } \\
\text { Review and/or Search }\end{array}$ \\
\hline
\end{tabular}

